Article

\title{
Preadmission Statin Therapy Is Associated with a Lower Incidence of Acute Kidney Injury in Critically Ill Patients: A Retrospective Observational Study
}

\author{
Tak Kyu Oh ${ }^{1, *}$, In-Ae Song ${ }^{1}$, Young-Jae Cho ${ }^{2}$, Cheong Lim ${ }^{3}$, Young-Tae Jeon ${ }^{1}$, Hee-Joon Bae ${ }^{4}$ \\ and You Hwan Jo ${ }^{5}$ \\ 1 Department of Anesthesiology and Pain Medicine, Seoul National University Bundang Hospital, \\ Gumi-ro 173 Beon-gil, Bundang-gu, Seongnam 13620, Korea; songoficu@outlook.kr (I.-A.S.); \\ ytjeon@snubh.org (Y.-T.J.) \\ 2 Division of Pulmonary and Critical Care Medicine, Department of Internal Medicine, Seoul National \\ University Bundang Hospital, Gumi-ro 173 Beon-gil, Bundang-gu, Seongnam 13620, Korea; \\ lungdrcho@snubh.org \\ 3 Department of Thoracic and Cardiovascular Surgery, Seoul National University Bundang Hospital, \\ Gumi-ro 173 Beon-gil, Bundang-gu, Seongnam 13620, Korea; mluemoon@snubh.org \\ 4 Department of Neurology, Stroke Center, Seoul National University Bundang Hospital, \\ Gumi-ro 173 Beon-gil, Bundang-gu, Seongnam 13620, Korea; braindoc@snubh.org \\ 5 Department of Emergency Medicine, Seoul National University Bundang Hospital, Gumi-ro 173 Beon-gil, \\ Bundang-gu, Seongnam 13620, Korea; drakejo@snubh.org \\ * Correspondence: airohtak@hotmail.com; Tel.: +82-31-787-7499
}

Received: 27 November 2018; Accepted: 20 December 2018; Published: 25 December 2018

\begin{abstract}
This study aimed to investigate the association between preadmission statin use and acute kidney injury (AKI) incidence among critically ill patients who needed admission to the intensive care unit (ICU) for medical care. Medical records of patients admitted to the ICU were reviewed. Patients who continuously took statin for $>1$ month prior to ICU admission were defined as statin users. We investigated whether preadmission statin use was associated with AKI incidence within $72 \mathrm{~h}$ after ICU admission and whether the association differs according to preadmission estimated glomerular filtration rate (eGFR; in $\mathrm{mL} \min ^{-1} 1.73 \mathrm{~m}^{-2}$ ). Among 21,236 patients examined, $5756(27.1 \%)$ were preadmission statin users and 15,480 (72.9\%) were non-statin users. Total AKI incidence within $72 \mathrm{~h}$ after ICU admission was $31 \%$ lower in preadmission statin users than in non-statin users [odds ratio (OR), $0.69 ; 95 \%$ confidence interval (CI), $0.61-0.79 ; p<0.001]$. This association was insignificant among

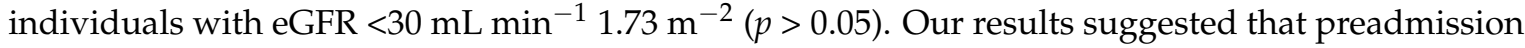
statin therapy is associated with a lower incidence of AKI among critically ill patients; however, this effect might not be applicable for patients with eGFR $<30 \mathrm{~mL} \mathrm{~min}^{-1} 1.73 \mathrm{~m}^{-2}$.
\end{abstract}

Keywords: acute kidney injury; statins; chronic kidney disease

\section{Introduction}

Acute kidney injury (AKI) is defined as a rapid worsening of renal functions [1] and affects $2-18 \%$ of inpatients and $57 \%$ of critical care patients [2-4]. AKI in critically ill patients in the intensive care unit (ICU) is an important issue because it delays recovery and increases hospital mortality [5]. Thus, appropriately preventing AKI in the ICU is currently an important task in ICU patient management [6].

Statin, known as a 3-hydroxy-3-methylglutaryl-coenzyme A inhibitor, is one of the most commonly prescribed drugs worldwide [7] that lowers the risk of cardiovascular death by 
reducing the serum cholesterol level [8]. Furthermore, statin has anti-inflammatory, antithrombotic, and immunomodulating effects [9,10], also known as "pleiotropic effects" [11]. These pleiotropic effects are reported to lower the incidence of surgery-related [12,13], contrast-induced [14], and sepsis-related AKI [15]. However, some study findings show that statin failed to improve the outcomes of kidney disease, and the debate regarding the relationship between statin use and AKI is ongoing [16]. Thus, further studies are needed to substantiate the inhibitory effects of statin on AKI. Additionally, considering that statin therapy may be discontinued for many patients based on their states after ICU admission, it is important to clarify the association between preadmission statin use and AKI incidence after ICU admission.

This study aimed to investigate the association between preadmission statin use and AKI incidence after ICU admission in the general adult population. Additionally, we examined whether this association differs with respect to pre-ICU kidney function.

\section{Materials and Method}

This retrospective observational study was approved by the Institutional Review Board (IRB) of Seoul National University Bundang Hospital (IRB approval number: B-1806/474-105). Because of the retrospective nature of the study, the IRB waived the need to obtain informed consent from the patients. All data for the study were collected by a medical records technician who was blinded to the purpose of this study.

\subsection{Patients}

The medical records of adult patients aged $\geq 18$ years who were admitted to the ICU between January 2012 and December 2017 were analyzed. When a patient was admitted to the ICU more than once during the study period, only data from the last ICU admission case, which might be the most severe, were included in the analysis. The exclusion criteria were as follows: (1) patients with an estimated glomerular filtration rate (eGFR; in $\mathrm{mL} \mathrm{min}^{-1} 1.73 \mathrm{~m}^{-2}$ ) of $<15$ or those with end-stage renal disease (ESRD) who were undergoing renal replacement therapy (RRT) prior to admission because they usually received RRT after ICU admission regardless of AKI development; (2) patients lacking information on baseline creatinine or creatinine level within $72 \mathrm{~h}$ after ICU admission; and (3) patients diagnosed with AKI prior to ICU admission.

\subsection{Preadmission Statin Use (Main Independent Variables)}

Preadmission statin users were defined as patients who confirmed taking statins as maintenance treatment as prescribed by their physicians at least one month before ICU admission. The other cases were classified as non-statin users. Statin was classified as atorvastatin, rosuvastatin, simvastatin, pitavastatin, and other statins (pravastatin, fluvastatin, and lovastatin).

\subsection{Measurements (Covariates)}

Demographic information (sex, age, and body mass index) of the patients and comorbidities at ICU admission, including Acute Physiology and Chronic Health Evaluation II score and eGFR, total serum cholesterol at ICU admission $\left(\mathrm{mg} \mathrm{dL}^{-1}\right)$, and data regarding admission to the emergency department and other departments (internal medicine, neurologic center, cardiothoracic surgical department, and other surgical departments) were collected. Pre-ICU admission eGFR was computed using the Modification of Diet in Renal Disease formula [17]: eGFR $\left(\mathrm{mL} \mathrm{min}{ }^{-1} 1.73 \mathrm{~m}^{-2}\right)=186 \times$ (creatinine level $)^{-1.154} \times(\text { age })^{-0.203} \times(0.742$ if female). Using the cut-off points of total cholesterol as 160 and $200 \mathrm{mg} / \mathrm{dL}$, which are known to be clinically meaningful, the subjects were divided into three groups $(<160,160-199$, and $\geq 200)[18,19]$. 


\subsection{Diagnosis of AKI (Dependent Variable)}

AKI was diagnosed based on the Kidney Disease: Improving Global Outcomes criteria and grading (Appendix A) [20]. Considering the varying lengths of urinary catheters used across patients, only serum creatinine $\left(\mathrm{mg} \mathrm{dL}^{-1}\right)$ was used for diagnosing AKI. Serum creatinine level measured at least within a month prior to ICU admission was defined as baseline creatinine, and AKI was diagnosed using serum creatinine levels measured within $72 \mathrm{~h}$ after ICU admission.

\subsection{Outcomes}

This study investigated how preadmission statin use is associated with the incidence of total AKI and stage $\geq 2$ AKI after ICU admission. Additionally, we examined how this association differs according to preadmission eGFR.

\subsection{Statistical Analysis}

The baseline characteristics of the patients were presented as means with standard deviation or numbers with percentage. To compare preadmission statin users and non-statin users, continuous variables were tested using the two-sample t-test, while categorical variables were tested using the chi-square test. First, the individual association between each covariate and total AKI was examined with univariable logistic regression analysis. The covariates with $p<0.1$ in the univariable logistic regression model were selected for adjustment in the final multivariable logistic regression analysis. Considering that baseline kidney function is a risk factor of AKI [21], we investigated the interaction between eGFR before ICU admission and preadmission statin use, and when there was an interaction, we performed a subgroup analysis by dividing the participants according to eGFR $(\geq 90,60-90,30-60$, and $<30 \mathrm{~mL} \mathrm{~min}^{-1} 1.73 \mathrm{~m}^{-2}$ ). In the subgroup analysis, the Bonferroni correction was used to prevent type I errors that resulted from multiple comparisons [22]. The same method was used for analyzing stage $\geq 2$ AKI as the dependent variable. All analyses were performed using IBM SPSS version 24.0 (IBM Corp., Armonk, NY, USA), and $p<0.05$ was considered statistically significant.

\section{Results}

A total of 30,398 patients were admitted to the ICU 40,533 times between January 2012 and December 2017. These 30,398 patients were selected after excluding 10,135 cases involving the same patient being admitted to the ICU more than once. Next, we excluded 5440 patients aged $<18$ years, 47 ESRD patients who were undergoing RRT prior to ICU admission, 970 patients without baseline creatinine data, 2170 patients whose creatinine level was not measured within $72 \mathrm{~h}$ after ICU admission, and 535 patients who were diagnosed with AKI prior to ICU admission. As a result, 21,236 patients were included in the analysis, of whom $5756(27.1 \%)$ were preadmission statin users and 15,480 (72.9\%) were non-statin users (Figure 1). Their baseline characteristics are presented in Table 1. A total of 5469 (25.8\%) patients developed AKI within $72 \mathrm{~h}$ after ICU admission, and $2216(10.4 \%)$ of them had stage $\geq 2$ AKI. Another 488 (2.3\%) patients began postoperative RRT within $72 \mathrm{~h}$ after ICU admission.

\subsection{Preadmission Statin Use and AKI Incidence}

Table 2 shows the differences in characteristics between statin and non-statin users. The incidence of total AKI and stage $\geq 2$ AKI among statin users was 1301/5756 (22.6\%) and 439/5756 (7.6\%), respectively, which was significantly lower than that in non-statin users [4168/15,480 (26.9\%) and $1777 / 15,480(11.5 \%)$, respectively] ( $p<0.001)$. Table 3 shows the results of the multivariable logistic analysis after adjusting for the covariates selected in the univariate logistic regression analysis for total AKI incidence (Appendix B). AKI incidence within $72 \mathrm{~h}$ after ICU admission was 31\% lower in preadmission statin users than in non-statin users [odds ratio (OR), $0.69 ; 95 \%$ confidence interval (CI), 0.61-0.79; $p<0.001$. Additionally, AKI incidence was 1.63-fold higher in patients with total cholesterol $<160 \mathrm{mg} \mathrm{dL}^{-1}$ (OR: $1.63,95 \% \mathrm{CI}, 1.45-1.83 ; p<0.001$ ) than in those with total cholesterol 
of $160-200 \mathrm{mg} \mathrm{dL}^{-1}$ at ICU admission. There was no significant difference in patients with total cholesterol $>200 \mathrm{mg} \mathrm{dL}^{-1}(p=0.111)$.

Table 1. Baseline characteristics of adults patients who were admitted to ICU in 2012-2017.

\begin{tabular}{|c|c|c|c|}
\hline Variable & Total $(21,236)$ & Mean & SD \\
\hline Sex: male & $12,434(58.6 \%)$ & & \\
\hline Age, year & & 64.0 & 15.8 \\
\hline Body mass index, $\mathrm{kg} \mathrm{m}^{-2}$ & & 23.7 & 3.9 \\
\hline APACHE II & & 20.0 & 10.0 \\
\hline \multicolumn{4}{|l|}{ Comorbidities at ICU admission } \\
\hline eGFR $^{\mathrm{a}} \geq 90$ & $12,993(61.2 \%)$ & & \\
\hline $60 \leq$ eGFR $^{a}<90$ & $4527(21.3 \%)$ & & \\
\hline $30 \leq \mathrm{eGFR}^{\mathrm{a}}<60$ & $2364(11.1 \%)$ & & \\
\hline$e^{e G F R}{ }^{a}<30$ & $1352(6.4 \%)$ & & \\
\hline Hypertension & $9346(44.0 \%)$ & & \\
\hline Diabetes mellitus & 1969 (9.3\%) & & \\
\hline Ischemic heart disease & $538(2.5 \%)$ & & \\
\hline Cerebrovascular disease & $945(4.4 \%)$ & & \\
\hline Chronic obstructive lung disease & $921(4.3 \%)$ & & \\
\hline Liver disease (LC, hepatitis, fatty liver) & $683(3.2 \%)$ & & \\
\hline Anemia $\left(\mathrm{Hb}<10 \mathrm{~g} \mathrm{dL}^{-1}\right)$ & $7569(35.6 \%)$ & & \\
\hline Cancer & $4308(20.3 \%)$ & & \\
\hline \multicolumn{4}{|l|}{ Characteristics of ICU admission } \\
\hline $\begin{array}{l}\text { Admission through emergency department } \\
\text { Admission department }\end{array}$ & $12,042(56.7 \%)$ & & \\
\hline Internal medicine & $4671(22.0 \%)$ & & \\
\hline Neurologic center & $4975(23.4 \%)$ & & \\
\hline Cardiothoracic surgical department & $6875(32.4 \%)$ & & \\
\hline Other surgical department & $4715(22.2 \%)$ & & \\
\hline Length of ICU stay, day & & 3.1 & 10.0 \\
\hline Length of hospital stay, day & & 12.9 & 20.1 \\
\hline Preadmission statin use & $5756(27.1 \%)$ & & \\
\hline Total serum cholesterol at ICU adm, $\mathrm{mg} \mathrm{dL}^{-1}$ & & 138.2 & 47.9 \\
\hline$<160, \mathrm{mg} \mathrm{dL}^{-1}$ & $8584(40.4 \%)$ & & \\
\hline $160-200 \mathrm{mg} \mathrm{dL}^{-1}$ & $10,751(50.6 \%)$ & & \\
\hline$>200 \mathrm{mg} \mathrm{dL}^{-1}$ & $1901(9.0 \%)$ & & \\
\hline \multicolumn{4}{|l|}{ Type of statin } \\
\hline Atorvastatin & $3456(16.3 \%)$ & & \\
\hline Rosuvastatin & $1391(6.6 \%)$ & & \\
\hline Simvastatin & $396(1.9 \%)$ & & \\
\hline Pitavastatin & $346(1.6 \%)$ & & \\
\hline Other statin ${ }^{b}$ & $167(0.8 \%)$ & & \\
\hline Total acute kidney injury & $5469(25.8 \%)$ & & \\
\hline Acute kidney injury stage $\geq 2$ & $2216(10.4 \%)$ & & \\
\hline RRT after ICU adm within $72 \mathrm{~h}$ & $488(2.3 \%)$ & & \\
\hline
\end{tabular}

Presented as Number (percentage) or Mean value (standard deviation): ${ }^{\text {a: }}$ eGFR (mL min ${ }^{-1} 1.73 \mathrm{~m}^{-2}$ ): $186 \times$ $(\text { Creatinine })^{-1.154} \times(\text { Age })^{-0.203} \times(0.742$ if female $)$; ${ }^{\text {b }}$ Other statin: Pravastatin, Fluvastatin, and Lovastatin; ICU, intensive care unit; APACHE, acute physiology and chronic health evaluation; eGFR, estimated glomerular filtration rate; LC, liver cirrhosis; $\mathrm{Hb}$, hemoglobin; RRT, renal replacement therapy.

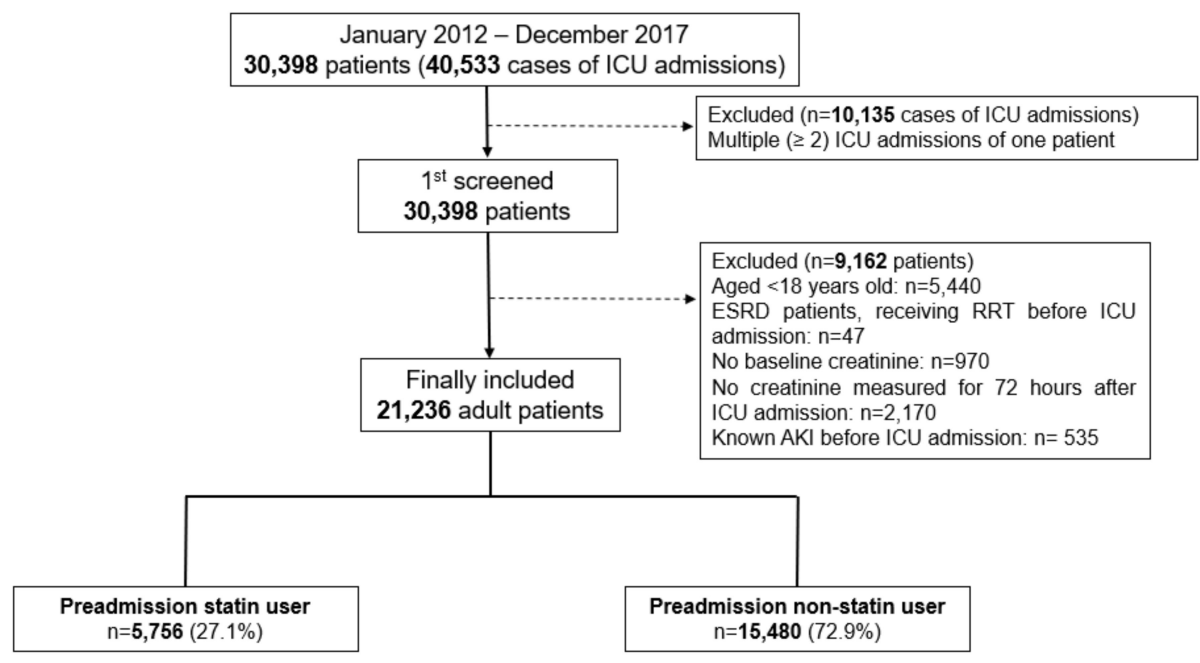

Figure 1. Flowchart of patient selection. ICU, Intensive Care Units; ESRD, End Stage Renal Disease; AKI, Acute Kidney Injury. 
Table 2. Comparison of characteristics between preadmission statin user and non-statin user.

\begin{tabular}{|c|c|c|c|}
\hline Variables & $\begin{array}{c}\text { Statin Group } \\
\quad n=5756\end{array}$ & $\begin{array}{c}\text { Non-Statin Group } \\
n=15,480\end{array}$ & $p$-Value \\
\hline Sex: male & $3398(59.0 \%)$ & $9036(58.4 \%)$ & 0.384 \\
\hline Age, year & $68.6(12.0)$ & $62.2(16.6)$ & $<0.001$ \\
\hline Body Mass Index, $\mathrm{kg} \mathrm{m}^{-2}$ & $24.6(3.8)$ & $23.3(3.8)$ & $<0.001$ \\
\hline \multicolumn{4}{|l|}{ Comorbidities at ICU admission } \\
\hline APACHE II & $19.8(9.8)$ & $20.2(10.1)$ & 0.012 \\
\hline eGFR $^{a}$ & & & $<0.001$ \\
\hline$\geq 90$ & $3073(53.4 \%)$ & $9920(64.1 \%)$ & \\
\hline $60-90$ & $1488(25.9 \%)$ & $3039(19.6 \%)$ & \\
\hline $30-60$ & $764(13.3 \%)$ & $1.600(10.3 \%)$ & \\
\hline$<30$ & $431(7.5 \%)$ & $921(5.9 \%)$ & \\
\hline Hypertension & $3672(63.8 \%)$ & $5674(36.7 \%)$ & $<0.001$ \\
\hline Diabetes mellitus & $830(14.4 \%)$ & $1139(7.4 \%)$ & $<0.001$ \\
\hline Ischemic heart disease & $314(5.5 \%)$ & $224(1.4 \%)$ & $<0.001$ \\
\hline Cerebrovascular disease & $505(8.8 \%)$ & $440(2.8 \%)$ & $<0.001$ \\
\hline Chronic obstructive lung disease & $229(4.0 \%)$ & $692(4.5 \%)$ & 0118 \\
\hline Liver disease (LC, hepatitis, fatty liver) & $87(1.5 \%)$ & $596(3.9 \%)$ & $<0.001$ \\
\hline Anemia $\left(\mathrm{Hb}<10 \mathrm{~g} \mathrm{dL}^{-1}\right)$ & $1774(30.8 \%)$ & $5795(37.4 \%)$ & $<0.001$ \\
\hline Cancer & $875(15.22 \%)$ & $3433(22.2 \%)$ & $<0.001$ \\
\hline Admission through ED & $2640(45.9 \%)$ & $9402(60.7 \%)$ & $<0.001$ \\
\hline Admission department & & & $<0.001$ \\
\hline Internal medicine & $1317(22.9 \%)$ & $3354(21.7 \%)$ & \\
\hline Neurologic center & $1252(21.8 \%)$ & $3723(24.1 \%)$ & \\
\hline Cardiothoracic surgical department & $2166(37.6 \%)$ & $4709(30.4 \%)$ & \\
\hline Other surgical department & $1021(17.7 \%)$ & $3694(23.9 \%)$ & \\
\hline Total serum cholesterol at ICU adm, $\mathrm{mg} \mathrm{dL}^{-1}$ & $125.2(37.6)$ & $143.1(50.4)$ & $<0.001$ \\
\hline Length of hospital stay, day & $11.3(22.5)$ & $13.5(19.0)$ & $<0.001$ \\
\hline Length of ICU stay, day & $2.5(15.3)$ & $3.3(7.2)$ & $<0.001$ \\
\hline Total acute kidney injury & $1301(22.6 \%)$ & $4168(26.9 \%)$ & $<0.001$ \\
\hline Acute kidney injury stage $\geq 2$ & $439(7.6 \%)$ & $1777(11.5 \%)$ & $<0.001$ \\
\hline RRT after ICU adm within $72 \mathrm{~h}$ & $140(2.4 \%)$ & $348(2.2 \%)$ & 0.426 \\
\hline
\end{tabular}

Presented as number (percentage) or mean value (standard deviation). Two sample t-test for continuous variables and chi-square test for categorical variables were used: ${ }^{a}$ : eGFR $\left(\mathrm{mL} \mathrm{min}^{-1} 1.73 \mathrm{~m}^{-2}\right): 186 \times(\text { Creatinine })^{-1.154} \times$ $(\text { Age })^{-0.203} \times(0.742$ if female); ICU, intensive care unit; APACHE, acute physiology and chronic health evaluation; eGFR, estimated glomerular filtration rate; LC, liver cirrhosis; Hb, hemoglobin; ED, emergency department; RRT, renal replacement therapy.

Table 3. Multivariable logistic regression analysis for occurrence of acute kidney injury during $72 \mathrm{~h}$ after ICU admission.

\begin{tabular}{|c|c|c|}
\hline \multirow{2}{*}{ Variable } & \multicolumn{2}{|c|}{ Multivariable Model } \\
\hline & Odds Ratio $(95 \% \mathrm{CI})$ & $p$-Value \\
\hline \multicolumn{3}{|l|}{ Dependent Variable: Total AKI } \\
\hline Model 1: Preadmission statin use & $0.69(0.61,0.79)$ & $<0.001$ \\
\hline \multicolumn{3}{|l|}{ Total serum cholesterol at ICU adm } \\
\hline $160-200 \mathrm{mg} \mathrm{dL}^{-1}$ & 1 & $<0.001$ \\
\hline$<160, \mathrm{mg} \mathrm{dL}^{-1}$ & $1.63(1.45,1.83)$ & $<0.001$ \\
\hline$>200 \mathrm{mg} \mathrm{dL}^{-1}$ & $0.86(0.72,1.04)$ & 0.111 \\
\hline Interaction: eGFR ${ }^{a} \geq 90 \times$ Non-statin use & 1 & 0.001 \\
\hline $60 \leq$ eGFR $^{\text {a }}<90 \times$ Statin use & $1.19(0.95,1.49)$ & 0.132 \\
\hline $30 \leq$ eGFR $^{\text {a }}<60 \times$ Statin use & $0.97(0.74,1.26)$ & 0.801 \\
\hline $\mathrm{eGFR}^{\mathrm{a}}<30 \times$ Statin use & $1.89(1.35,2.65)$ & $<0.001$ \\
\hline \multicolumn{3}{|l|}{ Dependent Variable: Stage $\geq 2$ AKI } \\
\hline Model 3: Preadmission statin use & $0.69(0.57,0.84)$ & $<0.001$ \\
\hline \multicolumn{3}{|l|}{ Total serum cholesterol at ICU adm } \\
\hline $160-200 \mathrm{mg} \mathrm{dL}^{-1}$ & 1 & $<0.001$ \\
\hline$<160 \mathrm{mg} \mathrm{dL}^{-1}$ & $1.66(1.38,1.99)$ & $<0.001$ \\
\hline$>200 \mathrm{mg} \mathrm{dL}^{-1}$ & $0.85(0.63,1.15)$ & 0.295 \\
\hline Interaction: eGFR ${ }^{a} \geq 90 \times$ Non-statin use & 1 & \\
\hline $60 \leq$ eGFR $^{\text {a }}<90 \times$ Statin use & $0.95(0.64,1.40)$ & 0.788 \\
\hline $30 \leq$ eGFR $^{\text {a }}<90 \times$ Statin use & $1.04(0.67,1.61)$ & 0.856 \\
\hline eGFR ${ }^{a}<30 \times$ Statin use & $1.27(0.85,1.91)$ & 0.242 \\
\hline
\end{tabular}

All covariates of $p<0.1$ in univariable logistic regression analysis were included in multivariable logistic regression analysis. ${ }^{a}$ : eGFR $\left(\mathrm{mL} \mathrm{min}^{-1} 1.73 \mathrm{~m}^{-2}\right): 186 \times(\text { Creatinine })^{-1.154} \times(\text { Age })^{-0.203} \times(0.742$ if female $)$ ICU, intensive care unit; AKI, acute kidney injury; eGFR, estimated glomerular filtration rate. 
An interaction occurred between eGFR before ICU admission and total AKI after ICU admission with respect to preadmission statin use (overall $p=0.001$, in Table 3; model 1); thus, additional subgroup analysis was performed (Table 4 ). When the patients were divided according to eGFR at ICU admission, total AKI incidence within $72 \mathrm{~h}$ after ICU admission was $28 \%$ lower among statin users with eGFR $\geq 90 \mathrm{~mL} \mathrm{~min}^{-1} 1.73 \mathrm{~m}^{-2}$ (OR, $\left.0.72 ; 95 \% \mathrm{CI}, 0.63-0.82 ; p<0.001\right), 26 \%$ lower among statin users with $60 \leq \mathrm{eGFR}<90 \mathrm{~mL} \mathrm{~min}^{-1} 1.73 \mathrm{~m}^{-2}$ (OR, 0.74; 95\% CI, 0.61-0.91; $p=0.004$ ), and 35\% lower among statin users with $30 \leq \mathrm{eGFR}<60 \mathrm{~mL} \mathrm{~min}^{-1} 1.73 \mathrm{~m}^{-2}$ (OR, $0.65 ; 95 \% \mathrm{CI}, 0.51-0.83 ; p=0.001$ ) than among non-statin users. Meanwhile, there were no significant differences in total AKI incidence between groups with eGFR $<30 \mathrm{~mL} \min ^{-1} 1.73 \mathrm{~m}^{-2}(p=0.095)$.

Table 4. Multivariable logistic regression analysis for occurrence of acute kidney injury during $72 \mathrm{~h}$ after ICU admission according to eGFR at ICU admission.

\begin{tabular}{|c|c|c|}
\hline \multirow{2}{*}{ Variable } & \multicolumn{2}{|c|}{ Multivariable Model } \\
\hline & Odds Ratio (95\% CI) & $p$-Value * \\
\hline $\mathrm{eGFR}^{\mathrm{a}} \geq 90(n=12,993)$ & & \\
\hline $\begin{array}{l}\text { Preadmission statin use } \\
60 \leq \text { eGFR }^{\mathrm{a}}<90(n=4527)\end{array}$ & $0.72(0.63,0.82)$ & $<0.001$ \\
\hline $\begin{array}{l}\text { Preadmission statin use } \\
30 \leq \text { eGFR }^{\mathrm{a}}<60(n=2364)\end{array}$ & $0.74(0.61,0.91)$ & 0.004 \\
\hline $\begin{array}{l}\text { Preadmission statin use } \\
\text { eGFR }^{\mathrm{a}}<30(n=1340)\end{array}$ & $0.65(0.51,0.83)$ & 0.001 \\
\hline Preadmission statin use & $1.33(0.95,1.86)$ & 0.095 \\
\hline
\end{tabular}

\subsection{Preadmission Statin Use and Stage $\geq 2$ AKI Incidence}

Table 3 also shows the results of the multivariable logistic regression analysis for stage $\geq 2$ AKI incidence, including the covariates selected in the univariable logistic regression analysis (Appendix C). Stage $\geq 2 \mathrm{AKI}$ incidence within $72 \mathrm{~h}$ after ICU admission was $31 \%$ lower among preadmission statin users than among non-statin users (OR, $0.69 ; 95 \% \mathrm{CI}, 0.57-0.84 ; p<0.001$; model 3). Additionally, stage $\geq 2$ AKI incidence was 1.66-fold higher in patients with total cholesterol $<160 \mathrm{mg} \mathrm{dL}^{-1}$ (OR: $1.66,95 \%$ CI, 1.38-1.99; $p<0.001$ ) than in those with total cholesterol of $160-200 \mathrm{mg} \mathrm{dL}^{-1}$ at ICU admission. There was no significant difference in patients with total cholesterol $>200 \mathrm{mg} \mathrm{dL}^{-1}(p=0.295)$. Moreover, no interaction occurred between eGFR at ICU admission and stage $\geq 2$ AKI with resto preadmission statin use (overall $p=0.788$ ).

\section{Discussion}

This study showed that preadmission statin use is associated with a lower incidence of AKI after ICU admission. This association was also evident with stage $\geq 2$ AKI. However, the association was not significant among patients with severe kidney dysfunction (eGFR $<30 \mathrm{~mL} \min ^{-1} 1.73 \mathrm{~m}^{-2}$ ) prior to ICU admission. Although the study results were derived from a retrospective observational study, it is striking because the statin group was comprised of significantly older and sicker patients and had a higher proportion of patients with renal dysfunction, more diabetes mellitus, ischemic heart disease, and cerebrovascular disease. Therefore, the study results suggested that clinicians who did not favor statin would consider prescribing statins to patients with respect to preventive effects for the development of AKI in critically ill patients.

The most interesting finding of this study was that an interaction occurred between eGFR at ICU admission and total AKI incidence with respect to preadmission statin use. In subsequent analyses, the potential benefit of preadmission statin use on AKI was not significant among patients with stage $\geq 4$ chronic kidney disease (CKD). A meta-analysis, published in 2015, reported that statin 
therapy does not improve the overall kidney function of CKD patients with eGFR $<60 \mathrm{~mL} \mathrm{~min}{ }^{-1}$ $1.73 \mathrm{~m}^{-2}$ and that high-dose statin therapy leads to limited improvement in kidney function [23]. Another meta-analysis, published in 2017, concluded that statin therapy was not beneficial in reducing major cardiovascular events, cardiovascular death, and all-cause mortality of patients with CKD 4 or 5 (eGFR $<30 \mathrm{~mL} \mathrm{~min}{ }^{-1} 1.73 \mathrm{~m}^{-2}$ ) [24]. Although the primary endpoints were different from those used in our study, the previous meta-analysis suggested that statin therapy did not improve outcomes of patients with severe kidney dysfunction (CKD stage $\geq 4$ ), which is consistent with our study finding. Patients with stage $\geq 4$ CKD have worse baseline renovascular function than patients with normal kidney function and thus are more susceptible to ischemic oxidative damage, which is a major mechanism of AKI [25]. Furthermore, it was possible that treating patients with CKD stage $\geq 4$ would be ineffective and the course of AKI could no longer be affected. However, it is difficult to completely explain the renal outcomes according to CKD stage solely based on this cohort study; hence, additional studies are needed.

This study suggested that preadmission statin therapy causes immunomodulatory effects, which were explained based on the pleiotropic effect of statin therapy [26]. We defined preadmission statin users as patients who confirmed taking statins as maintenance treatment as prescribed by their physicians at least one month before ICU admission. Most preadmission statin users received statin therapy for a long time, and there was some evidence that showed a clinical benefit of long-term statin therapy in patients with septic shock [27], pneumonia [28], or acute respiratory distress syndrome [29]. Although the immunomodulatory effect of statin therapy on critically ill patients remains controversial [30,31], it might affect the study results.

There is another important finding that should be carefully interpreted. The total incidence of AKI was higher in patients with $<160 \mathrm{mg} \mathrm{dL}^{-1}$ of total serum cholesterol than in those with $160-200 \mathrm{mg} \mathrm{dL}^{-1}$ of total serum cholesterol, while patients with $>200 \mathrm{mg} \mathrm{dL}^{-1}$ of total serum cholesterol had no association with the incidence of total AKI. In general, hyperlipidemia is an associated factor for renal damage [32]; however, hyperlipidemia was not associated with a lower incidence of AKI in this study. This can be explained based on the characteristics of ICU patients in this study. Lower cholesterol is a known factor that negatively affects the outcomes of critically ill patients [33,34], which is also coincident with our current study. Therefore, the effect of total serum cholesterol level on the incidence of AKI might be influenced by the characteristics of critically ill patients.

This study has a few limitations. First, a selection bias may have occurred due to the retrospective observational nature of the study. Second, the findings have limited generalizability because the study was conducted in a single center. For example, as previously mentioned, ethnical differences may have been involved in the effects of rosuvastatin. Lastly, because the duration of preadmission statin use differed among patients, we could not consider it in the analysis.

\section{Conclusions}

This study showed that preadmission statin use is associated with a lower incidence of total AKI and stage $\geq 2$ AKI among critically ill patients after ICU admission. This association was most significantly evident among rosuvastatin users, but was absent among CKD patients with eGFR $<30 \mathrm{~mL} \mathrm{~min}^{-1} 1.73 \mathrm{~m}^{-2}$.

Author Contributions: T.K.O. contributed to the study design, analyzed the data, and drafted the first manuscript; I.-A.S., Y.-J.C., C.L., Y.-T.J., H.-J.B., and Y.H.J. contributed to the acquisition of data and provided critical revision of the manuscript; All authors have given final approval for the final version of the manuscript.

Funding: This research received no external funding.

Conflicts of Interest: The authors declare no conflict of interest. 


\section{Appendix A. Staging of Postoperative Acute Kidney Injury (KDIGO)}

\begin{tabular}{cc}
\hline Stage & Serum Creatinine \\
\hline 1 & $1.5-1.9$ times baseline or $\geq 0.3 \mathrm{mg} \mathrm{dL}^{-1}$ increase within $72 \mathrm{~h}$ after ICU admission \\
2 & $\begin{array}{c}2.0-2.9 \text { times baseline within } 72 \mathrm{~h} \text { after ICU admission } \\
3\end{array}$ \\
$\begin{array}{c}3.0 \text { times baseline or increase in serum creatinine to } \geq 4.0 \mathrm{mg} \mathrm{dL}^{-1} \text { or initiation of RRT } \\
\text { within } 72 \mathrm{~h} \text { after ICU admission }\end{array}$ \\
\hline
\end{tabular}

KDIGO, Kidney Disease: Improving Global Outcomes; RRT, Renal Replacement Therapy.

\section{Appendix B. Univariable Logistic Regression Analysis of Covariates for Occurrence of Total Acute Kidney Injury during $72 \mathrm{~h}$ after ICU Admission}

\begin{tabular}{|c|c|c|c|}
\hline \multicolumn{2}{|l|}{ Variables } & Odds Ratio (95\% CI) & $p$-Value \\
\hline \multicolumn{2}{|l|}{ Sex: male } & $1.06(1.00-1.13)$ & 0.066 \\
\hline \multicolumn{2}{|l|}{ Age, year } & $1.02(1.02-1.02)$ & $<0.001$ \\
\hline \multicolumn{2}{|l|}{ Body mass index, $\mathrm{kg} \mathrm{m}^{-2}$} & $0.96(0.95-0.97)$ & $<0.001$ \\
\hline \multicolumn{2}{|l|}{ APACHE II } & $1.04(1.04-1.04)$ & $<0.001$ \\
\hline \multicolumn{4}{|c|}{ Comorbidities at ICU admission } \\
\hline \multirow{2}{*}{\multicolumn{2}{|c|}{$\begin{array}{l}\text { Hypertension } \\
\text { Diabetes mellitus }\end{array}$}} & $1.26(1.18-1.34)$ & $<0.001$ \\
\hline & & $1.46(1.32-1.61)$ & $<0.001$ \\
\hline \multicolumn{2}{|c|}{ Ischemic heart disease } & $1.17(0.97-1.42)$ & 0.101 \\
\hline \multicolumn{2}{|c|}{ Cerebrovascular disease } & $1.31(1.14-1.51)$ & $<0.001$ \\
\hline \multicolumn{2}{|c|}{ Chronic obstructive lung disease } & $1.13(0.97-1.31)$ & 0.109 \\
\hline \multicolumn{2}{|c|}{ Liver disease (LC, hepatitis, fatty liver) } & $2.48(2.13-2.89)$ & $<0.001$ \\
\hline \multicolumn{2}{|c|}{ Anemia $\left(\mathrm{Hb}<10 \mathrm{~g} \mathrm{dL}^{-1}\right)$} & $3.82(3.58-4.07)$ & $<0.001$ \\
\hline \multicolumn{2}{|c|}{ Cancer } & $1.90(1.77-2.05)$ & $<0.001$ \\
\hline \multicolumn{4}{|c|}{ eGFR $\mathrm{mL} \min ^{-1} 1.73 \mathrm{~m}^{-2}$} \\
\hline & $\geq 90$ & 1 & $<0.001$ \\
\hline & $60-90$ & $0.99(0.91-1.07)$ & 0.731 \\
\hline & $30-60$ & $2.08(1.89-2.28)$ & $<0.001$ \\
\hline & $<30$ & $5.18(4.61-5.82)$ & $<0.001$ \\
\hline \multicolumn{2}{|c|}{ Admission through emergency department } & $1.52(1.43-1.62)$ & $<0.001$ \\
\hline \multicolumn{4}{|c|}{ Total serum cholesterol at ICU adm } \\
\hline \multicolumn{2}{|c|}{$160-200 \mathrm{mg} \mathrm{dL}^{-1}$} & 1 & $<0.001$ \\
\hline \multicolumn{2}{|l|}{$<160, \mathrm{mg} \mathrm{dL}^{-1}$} & $2.21(2.01,2.43)$ & $<0.001$ \\
\hline \multicolumn{2}{|l|}{$>200 \mathrm{mg} \mathrm{dL}^{-1}$} & $0.81(0.69,0.94)$ & $<0.001$ \\
\hline \multicolumn{4}{|l|}{ Admission department } \\
\hline \multicolumn{2}{|c|}{ Internal medicine } & 1 & $<0.001$ \\
\hline \multicolumn{2}{|c|}{ Neurologic center } & $0.25(0.23-0.28)$ & $<0.001$ \\
\hline & Cardiothoracic surgical department & $0.78(0.72-0.84)$ & $<0.001$ \\
\hline & Other surgical department & $0.83(0.76-0.90)$ & $<0.001$ \\
\hline \multicolumn{4}{|l|}{ Year at ICU admission } \\
\hline \multicolumn{2}{|l|}{2012} & 1 & $<0.001$ \\
\hline \multicolumn{2}{|l|}{2013} & $1.31(1.16-1.48)$ & $<0.001$ \\
\hline \multicolumn{2}{|l|}{2014} & $1.26(1.12-1.42)$ & $<0.001$ \\
\hline 2015 & & $1.09(0.97-1.23)$ & 0.150 \\
\hline 2016 & & $1.02(0.91-1.15)$ & 0.690 \\
\hline 2017 & & $0.96(0.86-1.08)$ & 0.535 \\
\hline
\end{tabular}

All covariates of $p<0.1$ in univariable logistic regression analysis were included in multivariable logistic regression analysis; ICU, intensive care unit; AKI, acute kidney injury; APACHE, acute physiology and chronic health evaluation; LC, liver cirrhosis; $\mathrm{Hb}$, hemoglobin. 
Appendix C. Univariable Logistic Regression Analysis of Covariates for Occurrence of Stage $\geq$ 2 AKI Acute Kidney Injury during $72 \mathrm{~h}$ after ICU Admission

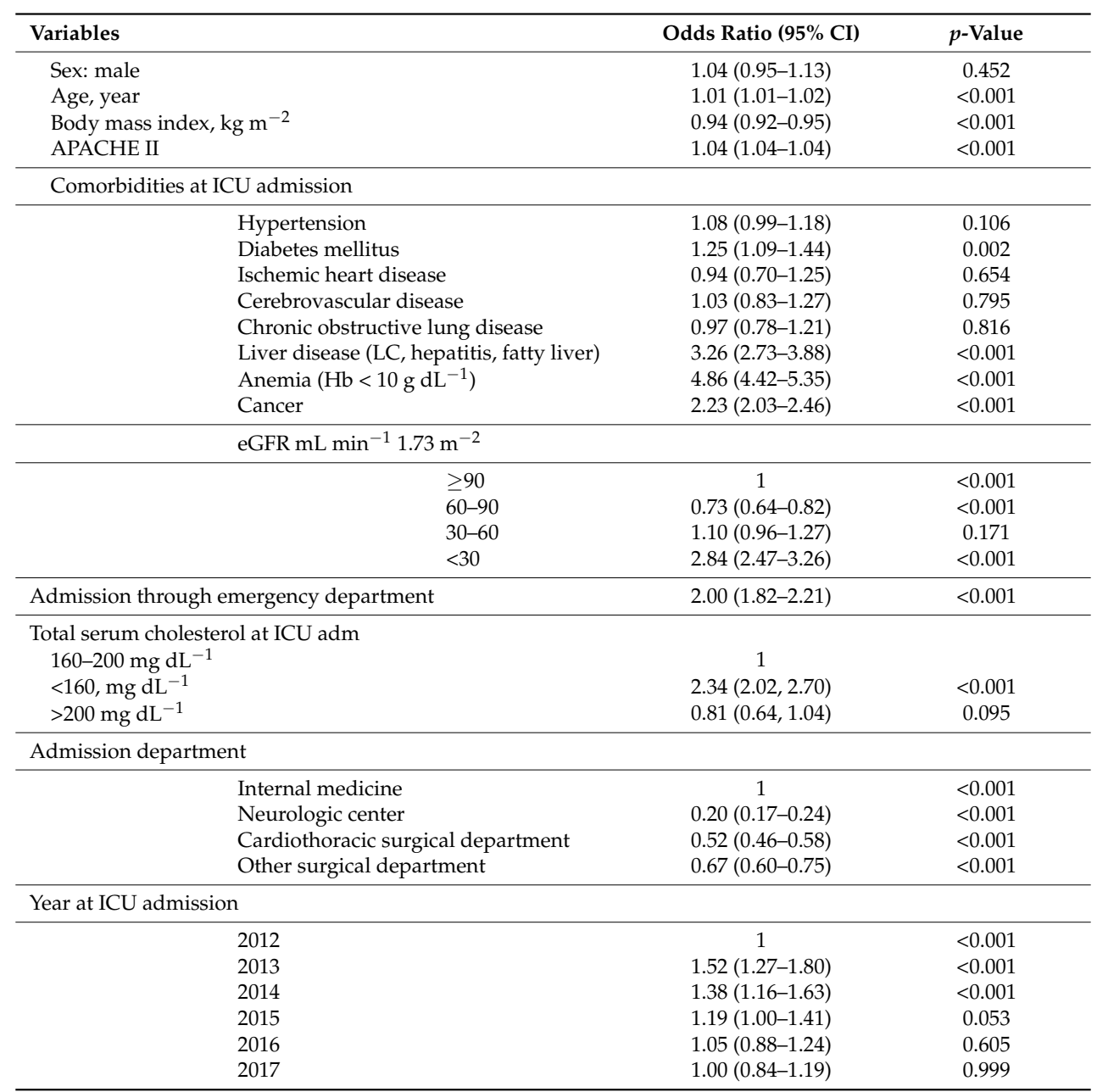

All covariates of $p<0.1$ in univariable logistic regression analysis were included in multivariable logistic regression analysis. ICU, intensive care unit; APACHE, acute physiology and chronic health evaluation; eGFR, estimated glomerular filtration rate; LC, liver cirrhosis; Hb, hemoglobin; RRT, renal replacement therapy.

\section{References}

1. Waikar, S.S.; Bonventre, J.V. Creatinine kinetics and the definition of acute kidney injury. J. Am. Soc. Nephrol. 2009, 20, 672-679. [CrossRef] [PubMed]

2. Bellomo, R.; Kellum, J.A.; Ronco, C. Acute kidney injury. Lancet 2012, 380, 756-766. [CrossRef]

3. Lewington, A.J.; Cerda, J.; Mehta, R.L. Raising awareness of acute kidney injury: A global perspective of a silent killer. Kidney Int. 2013, 84, 457-467. [CrossRef] [PubMed]

4. Nash, K.; Hafeez, A.; Hou, S. Hospital-acquired renal insufficiency. Am. J. Kidney Dis. 2002, 39, 930-936. [CrossRef] [PubMed]

5. Thakar, C.V.; Christianson, A.; Freyberg, R.; Almenoff, P.; Render, M.L. Incidence and outcomes of acute kidney injury in intensive care units: A veterans administration study. Crit. Care Med. 2009, 37, 2552-2558. [CrossRef]

6. Macedo, E.; Mehta, R.L. Preventing acute kidney injury. Crit. Care Clin. 2015, 31, 773-784. [CrossRef] [PubMed]

7. Santodomingo-Garzon, T.; Cunha, T.M.; Verri, W.A., Jr.; Valerio, D.A.; Parada, C.A.; Poole, S.; Ferreira, S.H.; Cunha, F.Q. Atorvastatin inhibits inflammatory hypernociception. Br. J. Pharmacol. 2006, 149, 14-22. [CrossRef] [PubMed] 
8. Rosenson, R.S. Low high-density lipoprotein cholesterol and cardiovascular disease: Risk reduction with statin therapy. Am. Heart J. 2006, 151, 556-563. [CrossRef]

9. Novack, V.; Terblanche, M.; Almog, Y. Do statins have a role in preventing or treating sepsis? Crit. Care 2006, 10, 113. [CrossRef]

10. Terblanche, M.; Almog, Y.; Rosenson, R.S.; Smith, T.S.; Hackam, D.G. Statins and sepsis: Multiple modifications at multiple levels. Lancet Infect Dis. 2007, 7, 358-368. [CrossRef]

11. Wang, C.Y.; Liu, P.Y.; Liao, J.K. Pleiotropic effects of statin therapy: Molecular mechanisms and clinical results. Trends Mol. Med. 2008, 14, 37-44. [CrossRef] [PubMed]

12. Molnar, A.O.; Coca, S.G.; Devereaux, P.J.; Jain, A.K.; Kitchlu, A.; Luo, J.; Parikh, C.R.; Paterson, J.M.; Siddiqui, N.; Wald, R.; et al. Statin use associates with a lower incidence of acute kidney injury after major elective surgery. J. Am. Soc. Nephrol. 2011, 22, 939-946. [CrossRef] [PubMed]

13. Campbell, J. Hmg coa reductase inhibitors (statins) for preventing acute kidney injury after surgical procedures requiring cardiac bypass. J. Perioper. Pract. 2018, 28, 142-143. [CrossRef] [PubMed]

14. Han, Y.; Zhu, G.; Han, L.; Hou, F.; Huang, W.; Liu, H.; Gan, J.; Jiang, T.; Li, X.; Wang, W.; et al. Short-term rosuvastatin therapy for prevention of contrast-induced acute kidney injury in patients with diabetes and chronic kidney disease. J. Am. Coll. Cardiol. 2014, 63, 62-70. [CrossRef] [PubMed]

15. Yasuda, H.; Yuen, P.S.; Hu, X.; Zhou, H.; Star, R.A. Simvastatin improves sepsis-induced mortality and acute kidney injury via renal vascular effects. Kidney Int. 2006, 69, 1535-1542. [CrossRef] [PubMed]

16. Su, X.; Zhang, L.; Lv, J.; Wang, J.; Hou, W.; Xie, X.; Zhang, H. Effect of statins on kidney disease outcomes: A systematic review and meta-analysis. Am. J. Kidney Dis. 2016, 67, 881-892. [CrossRef] [PubMed]

17. Hallan, S.; Asberg, A.; Lindberg, M.; Johnsen, H. Validation of the modification of diet in renal disease formula for estimating gfr with special emphasis on calibration of the serum creatinine assay. Am. J. Kidney Dis. 2004, 44, 84-93. [CrossRef] [PubMed]

18. Neaton, J.D.; Blackburn, H.; Jacobs, D.; Kuller, L.; Lee, D.J.; Sherwin, R.; Shih, J.; Stamler, J.; Wentworth, D. Serum cholesterol level and mortality findings for men screened in the multiple risk factor intervention trial. Multiple risk factor intervention trial research group. Arch. Intern. Med. 1992, 152, 1490-1500. [CrossRef] [PubMed]

19. Sempos, C.T.; Cleeman, J.I.; Carroll, M.D.; Johnson, C.L.; Bachorik, P.S.; Gordon, D.J.; Burt, V.L.; Briefel, R.R.; Brown, C.D.; Lippel, K.; et al. Prevalence of high blood cholesterol among us adults. An update based on guidelines from the second report of the national cholesterol education program adult treatment panel. JAMA 1993, 269, 3009-3014. [CrossRef] [PubMed]

20. Kellum, J.A.; Lameire, N.; Group, K.A.G.W. Diagnosis, evaluation, and management of acute kidney injury: A kdigo summary (part 1). Crit. Care 2013, 17, 204. [CrossRef] [PubMed]

21. Chawla, L.S.; Eggers, P.W.; Star, R.A.; Kimmel, P.L. Acute kidney injury and chronic kidney disease as interconnected syndromes. N. Engl. J. Med. 2014, 371, 58-66. [CrossRef]

22. Armstrong, R.A. When to use the bonferroni correction. Ophthalmic Physiol. Opt. 2014, 34, 502-508. [CrossRef]

23. Sanguankeo, A.; Upala, S.; Cheungpasitporn, W.; Ungprasert, P.; Knight, E.L. Effects of statins on renal outcome in chronic kidney disease patients: A systematic review and meta-analysis. PLoS ONE 2015, 10, e0132970. [CrossRef]

24. Messow, C.M.; Isles, C. Meta-analysis of statins in chronic kidney disease: Who benefits? QJM 2017, 110, 493-500. [CrossRef] [PubMed]

25. Basile, D.P.; Anderson, M.D.; Sutton, T.A. Pathophysiology of acute kidney injury. Compr. Physiol. 2012, 2, 1303-1353. [PubMed]

26. Liao, J.K.; Laufs, U. Pleiotropic effects of statins. Annu. Rev. Pharmacol. Toxicol. 2005, 45, 89-118. [CrossRef] [PubMed]

27. Fuller, B.M.; Gajera, M.; Schorr, C.; Gerber, D.; Dellinger, R.P.; Zanotti, S. The association of prior statin use in septic shock treated with early goal directed therapy. Eur. J. Emerg. Med. 2012, 19, 226-230. [CrossRef] [PubMed]

28. Thomsen, R.W.; Riis, A.; Kornum, J.B.; Christensen, S.; Johnsen, S.P.; Sorensen, H.T. Preadmission use of statins and outcomes after hospitalization with pneumonia: Population-based cohort study of 29,900 patients. Arch. Intern. Med. 2008, 168, 2081-2087. [CrossRef]

29. Craig, T.; O'Kane, C.; McAuley, D. Potential mechanisms by which statins modulate the development of acute lung injury. In Intensive Care Medicine; Springer: Berlin, Germany, 2007; pp. 276-288. 
30. Nagendran, M.; McAuley, D.F.; Kruger, P.S.; Papazian, L.; Truwit, J.D.; Laffey, J.G.; Thompson, B.T.; Clarke, M.; Gordon, A.C. Statin therapy for acute respiratory distress syndrome: An individual patient data meta-analysis of randomised clinical trials. Intensive Care Med. 2017, 43, 663-671. [CrossRef]

31. Thomas, G.; Hraiech, S.; Loundou, A.; Truwit, J.; Kruger, P.; McAuley, D.F.; Papazian, L.; Roch, A. Statin therapy in critically-ill patients with severe sepsis: A review and meta-analysis of randomized clinical trials. Minerva Anestesiol. 2015, 81, 921-930.

32. Sastre, C.; Rubio-Navarro, A.; Buendia, I.; Gomez-Guerrero, C.; Blanco, J.; Mas, S.; Egido, J.; Blanco-Colio, L.M.; Ortiz, A.; Moreno, J.A. Hyperlipidemia-associated renal damage decreases klotho expression in kidneys from apoe knockout mice. PLoS ONE 2013, 8, e83713. [CrossRef] [PubMed]

33. Wilson, R.F.; Barletta, J.F.; Tyburski, J.G. Hypocholesterolemia in sepsis and critically ill or injured patients. Crit. Care 2003, 7, 413-414. [CrossRef] [PubMed]

34. Gui, D.; Spada, P.L.; De Gaetano, A.; Pacelli, F. Hypocholesterolemia and risk of death in the critically ill surgical patient. Intensive Care Med. 1996, 22, 790-794. [CrossRef] [PubMed]

(C) 2018 by the authors. Licensee MDPI, Basel, Switzerland. This article is an open access article distributed under the terms and conditions of the Creative Commons Attribution (CC BY) license (http:/ / creativecommons.org/licenses/by/4.0/). 